\title{
Implementation of Good Governance Principles in the Public Information Disclosure Policy
}

\author{
Dila Novita $^{1}$, Mawar Agustina Malela ${ }^{2}$, Adi Susila ${ }^{3}$, \\ Muhammad Fadhil $^{4}$, Elvira Suryani ${ }^{5}$, Muhammad Yunus ${ }^{6}$ \\ \{dilanovitapasca@gmail.com ${ }^{*}$, rosemalelaa@gmail.com ${ }^{2}$, adisusilo17@gmail.com ${ }^{3}$, \\ fadil@unismabekasi.ac.id ${ }^{4}$, vira_surya@gmail.com ${ }^{5}$,map_yunus@yahoo.co.id $\left.{ }^{6}\right\}$ \\ Faculty of Social and Political Sciences, Islamic University ‘ 45 ' Bekasi City, Indonesia
}

\begin{abstract}
The openness of public information is an inseparable aspect of democracy that upholds freedom and human rights. As an effort to encourage this, Law Number 14 of 2008 was born. Public information disclosure is one of the essential elements for the realization of good governance. Based on this, this study intends to analyze the Implementation of the Public Information Disclosure Policy in the application of the principles of good governance in the management of the website of the Provincial Government of the Special Capital Region of Jakarta. The researcher examines this matter by using the constructivism paradigm with qualitative research methods accompanied by a case study research approach. Data collection techniques include observation, in-depth interviews, literature study, and documentation. The study results show that the Decree of the Governor of the Special Capital Region of Jakarta Number 839 of 2017 concerning Information Management and Documentation Officers (PPID) within the Provincial Government of the Special Capital City Region Jakarta is a reference in implementing Public Information Disclosure. Through this regulation, every public agency must be transparent about public information under its authority and is expected to accelerate the implementation of information disclosure in DKI Jakarta. In the service of public information disclosure, the DKI Jakarta Provincial Government makes optimal use of use of government websites as a medium for disseminating information and government policies. On November 21, 2019, the DKI Jakarta Provincial Government received an award from the Central Information Commission of the Republic of Indonesia for the category "Informative Qualification Provincial Government Public Agency."
\end{abstract}

Keywords: Good Governance; Public Information Disclosure

\section{Introduction}

Disclosure of public information is a crucial aspect that cannot be separated and cannot be separated from a democracy that upholds freedom and human rights $[1 ; 2 ; 3]$. In addition, the disclosure of public information is also an essential aspect of democracy in the fulfillment of individual rights to public information [4;5]. In Indonesia, the recognition of access to 
information is considered as one of the human rights. It is stated in the 1945 Constitution in Article 28F and other laws such as Law No. 39 of 1999 concerning Human Rights. Law No.40 of 1999 concerning the Press Article 4 and Law No.28 of 1999 concerning the implementation of a Clean and KKN-free State in Article 9 Paragraph (1). In addition, the recognition of access to information as a human right is also stated in Article 19 of the International Covenant on Civil and Political Rights and Article 19 of the United Nations Universal Declaration of Human Rights in 1946 [6; 7]. These laws show that the right to information is a crucial aspect in creating and growing an established democracy. This sustainable development process favors the community and the eradication of corruption [8;9].

To encourage public information disclosure, Law Number 14 of 2008 concerning Public Information Disclosure (UU KIP) was issued, ratified by the House of Representatives of the Republic of Indonesia on April 3, 2008 [10; 11]. It is crucial and essential for every society for personal development and social environment, besides that become an important part of national security by Article $28 \mathrm{~F}$ of the 1945 Constitution. The UU KIP is effective as of May 1,2010 . The openness of public information is one of the crucial elements for realizing good Governance or Good Governance in government administration [12]. Good Governance is defined as the effective management of public affairs through legal regulations and policies to promote social values $[13 ; 14]$. In disclosing public information, several principles can realize good governance: participation, transparency, accountability, independence, and accountability. Disclosure of information is essential because, in a closed government, it is prone to irregularities and misuse $[15 ; 16]$. Public information that should be made available to the public is only controlled by a small group of government elites who encourage abuses such as corruption, collusion, and nepotism [17; 18; 19].

Good governance is the hottest issue in the public sector and is the main prerequisite for realizing people's aspirations in achieving the goals and ideals of the nation and state [20]. Therefore, it is necessary to develop and implement an appropriate, clear, and natural accountability system so that government administration, development, and society can occur in an efficient, effective, clean, and responsible manner. It is also the case with the Provincial Government of Jakarta's Special Capital City Region, which seeks to improve or reform to create good governance. As an effort to encourage the disclosure of public information in realizing Good Governance, the Provincial Government of the Special Capital Region of Jakarta has implemented Law Number 14 of 2008 (UU KIP) and formed a derivative regulation, namely the Decree of the Governor of the Special Capital Region of Jakarta Number 839 of 2017 concerning Information Management Officers and Documentation (PPID) within the Provincial Government of the Special Capital Region of Jakarta. With this regulation, every public agency is required to be transparent about public information under its authority, and it is also expected to hasten the implementation of information disclosure in DKI Jakarta by the Law on Public Information Disclosure.

In this public information disclosure service, the Provincial Government of DKI Jakarta uses the government website as a medium for disseminating agenda information and policies in government. Services regarding Public Information Disclosure are also strengthened by the Presidential Instruction No. 3 of 2003 concerning national policies and strategies for egovernment development, which is the government's seriousness in organizing and utilizing information technology infrastructure. According to data from the Central Information Commission regarding the disclosure of information on public bodies in Indonesia in 2018, DKI Jakarta is already in second place with an index score of 93.19. DKI Jakarta Province is under Central Java Province with a score of 96.95.

Table 1. Categories Board of Public Government Provincial Qualifying Informative 


\begin{tabular}{rll}
\hline 1 & Government of the Province of Central Java & Informative, Value 96.95 \\
2 & DKI Jakarta Provincial Government & Informative, Value 93.19 \\
3 & Government of the Province of West Kalimantan & Informative, Rated 90.53 \\
4 & Government of the Province West Java & Informative, Value 90.32 \\
\hline Source: Website of the Central Information Commission of the Republic of Indonesia
\end{tabular}

On November 21, 2019, the DKI Jakarta Provincial Government was awarded an award by the Republic of Indonesia's Central Information Commission (KI) for "Informative Qualification Provincial Government Public Agency." The Governor of DKI Jakarta Province, Anies Baswedan, together with the Head of the DKI Jakarta Provincial Communication, Information and Statistics Agency, Atika Nur Rahmania, received the award given by the Vice President of the Republic of Indonesia Ma'ruf Amin at the office of the Vice President of the Republic of Indonesia [21].

The assessment results with the highest appreciation from the Monitoring and Evaluation of Public Information Disclosure in 2019 for Informative Qualification Public Bodies; there are 34 Public Bodies divided into 7 (seven) categories. Among the 34 Informative Qualification Public Bodies, there are 8 (eight) Provincial Governments that are included in the "Informative Qualification Provincial Government Public Agency" award category, namely: DKI Jakarta Provincial Government, West Java Provincial Government, Central Java Provincial Government, West Kalimantan Provincial Government, West Nusa Tenggara Provincial Government, Riau Provincial Government, West Sumatra Provincial Government, and North Sumatra Provincial Government.

Based on the background and problems described above, this research aims to 1 . Analyzing the Implementation of the Public Information Disclosure Policy in the implementation principles of Good Governance in the management of the DKI Jakarta Provincial Government website. 2. Analyzing the supporting factors for the Implementation of the Public Information Disclosure Policy in applying the principles of Good Governance in the management of the DKI Jakarta Provincial Government website. 3. Analyzing the inhibiting factors for the Implementation of the Public Information Disclosure Policy in applying the principles of Good Governance in the management of the DKI Jakarta Provincial Government website. 4. Analyzing the public's assessment of the implementation of the Public Information Disclosure Policy in applying the principles of Good Governance in the management of the DKI Jakarta Provincial Government website.

\subsection{Good Governance}

The term governance is not the same as government. The concept of "government" refers to a management organization based on the highest authority (state and government). The concept of "governance" encompasses both the government and the state and the roles of various actors outside of the government and the state, so the parties involved are also diverse [22]. The concept of governance in society is often confused with the government. The concept of governance is more inclusive than government [23]. The concept of government refers to a management organization based on the highest authority (State and government) [24]. The concept of governance involves the government and the state so that the parties involved are also inclusive.

In Government Regulation (PP) Number 101 of 2000, the definition of Good Governance is formulated as a government that develops and applies the principles of professionalism, accountability, transparency, excellent service, democracy, efficiency, effectiveness, the rule 
of law and can be accepted by the whole community. According to the United Nations Development Program (UNDP) Good Governance implies a synergistic and constructive relationship between the state, the private sector, and the community [25; 26; 27]. Charlick [28] defines good governance as the effective management of all kinds of public affairs through legal regulations and policies to promote social values. While Landell-Mills \& Seregeldin [29], Good Governance uses political authority and power to manage resources for socio-economic development.

Good Governance can be interpreted as a principle in regulating government that allows efficient public services, a reliable court system, and an administrative system accountable to the public $[30 ; 31]$. Another opinion is that while the OECD and the World Bank, Good Governance is an implementation of solid and responsible development management that is in line with the principles of democracy and an efficient market, avoiding misallocation of investment funds, and preventing corruption both politically $[32 ; 33]$. As well as administrative, implementing budgetary discipline and creating a political and legal framework for the growth of entrepreneurial activity [34]. From the various definitions of Good Governance, it can be concluded that Good Governance is a government that fosters a synergistic relationship between the government, the private sector, and the community to manage resources for socio-economic development effectively and efficiently. Good governance, according to the Good Governance Development Team (BPKP) [35] suggests that the principles developed in good governance are:

a) Participation

Both men and women must have the same voting rights in the decision-making process, either directly or through representative institutions by their interests and aspirations.

b) Transparency

It must be built within the framework of free information flow, with various processes, institutions, and information freely accessible to those in need and information provided adequately and efficiently understood to be used as a monitoring and evaluation tool.

c) Accountability

Decision-makers in service sector organizations and civil society citizens have a responsibility to the public and stakeholders; the responsibilities vary depending on the type of organizational decision that is internal or external.

d) Independency

In carrying out its roles and responsibilities, the government must be free from all forms of possibilities that can cause conflicts of interest. It is necessary to ensure that decisionmaking is carried out independently, free from any form of pressure from other parties.

e) Responsibility

Organizations must comply with laws and regulations and carry out responsibilities to society and the environment to maintain long-term business continuity. Each individual is responsible for all his actions by the assigned tasks.

\subsection{Public Policy Implementation}

Van Meter and Van Horn [36; 37] define the implementation of public policy as actions in previous decisions. These actions include efforts to turn decisions into operational actions within a certain period and in the context of continuing efforts to achieve significant and small changes determined by policy decisions made by public organizations that are directed to achieve the goals that have been set. According to Daniel A. Mazmanian and Paul Sabatier [38], the meaning of implementation is understanding what happens after a program is declared valid or 
formulated, namely events. - events and activities that occur following the ratification of state policy guidelines, including both efforts to administer them and to have real consequences/impacts on society or events. Events and activities that occur following the ratification of state policy guidelines, including both efforts to administer them and to have real consequences/impacts on society or events.

From the explanations above, it can be concluded that policy implementation will not begin before the goals and objectives are determined or identified by policy decisions. So, implementation is a process of activities carried out by various actors so that in the end, it will get a result that is by the goals or objectives policy goals themselves. Edwards III [39] proposes an approach to implementation problems by suggesting that there are two primary questions, namely: (i) what factors support the success of policy implementation and (ii) what factors can hinder the success of policy implementation. From these two questions, four factors can be formulated that can be used as the main requirements for the success of the process in implementation, namely the existence of communication, resources, bureaucratic or implementer attitudes, and organizational structure, including bureaucratic governance workflow. These four factors are essential criteria in implementing a policy and are interrelated with each other:

a) Communication

Implementation will be effective if the measures and policy objectives are understood by the individuals responsible for achieving the policy objectives. Communication in organizations is a very complex and complicated process. One can hold it for a particular purpose or disseminate it. In addition, different sources of information will also give birth to different interpretations;

b) Resources

This resource component includes the number of staff, expertise of implementers, relevant and sufficient information to implement policies and related resources in program implementation that can be directed to what is expected as well as the existence of supporting facilities that can be used to carry out program activities such as funds and infrastructure;

c) Disposition

One of the factors that influence the effectiveness of policy implementation is the attitude of the implementor. If the implementors agree with the contents of the policy, then they will carry out with the policymakers then the implementation process will experience many problems. There are three attitudes/responses of the implementer to the policy: the implementer's awareness, the implementer's instructions/directions to respond to the program in terms of acceptance or rejection, and the intensity of the response.

d) Bureaucratic Structure

Discussing the implementing agency of a policy cannot be separated from the bureaucratic structure. Bureaucratic structures are characteristics, norms, and patterns of relationships that repeatedly occur in executive bodies that have both potential and accurate relationships with what they have in carrying out policies.

\subsection{Community Assessment}

The definition of community assessment is often confused, this is only distinguished by who the provider is and the motive for providing the service. Service providers in public services are employees of government agencies who carry out mandated public service tasks and recipients of public services (people, communities, institutions, government agencies, and the business world) who benefit from the activity of providing public services [40]. Service satisfaction is based on Kep./25/M.PAN/2/2004, namely "the results of public opinion and assessment of the 
performance of services provided by public service providers." Community assessment consists of 1. Tangibles (direct evidence); Includes physical facilities, equipment, employees, and means of communication. 2. Reliability (reliability); Ability to provide services quickly and satisfactorily following what has been promised. 3. Responsiveness (capturing power); The desire of the staff to help customers and provide responsive service. 4. Assurance; Includes courtesy, character, and ability that can be trusted by staff, free from danger, risk, or doubt. 5 . Empathy; Providing convenience in establishing good communication, relationships, and sincere attention to the needs of consumers or customers $[41 ; 42 ; 43]$.

\section{Methodology}

The paradigm in this research is the constructivism paradigm. This paradigm views social science as a systematic analysis of socially meaningful action through direct and detailed observations of the social actors concerned in creating and maintaining/managing their social world [44]. The researcher uses the constructivism paradigm in this study because of this paradigm. The researcher can conduct a systematic analysis to understand and interpret how the Public Information Disclosure Policy is implemented; the researcher can conduct a systematic analysis. Observation of the Implementation of the Public Information Disclosure Policy in applying the principles of Good Governance in the management of the website of the Provincial Government of the Special Capital Region of Jakarta. The application of the principles of Good Governance is carried out.

Qualitative research emphasizes the importance of understanding how people interpret various events in their lives [45]. With an inductive mindset, the researcher draws extraordinary things that he encounters in every incident where he makes observations into general conclusions that refer to behavioral patterns or assumptions from social events or actions carried out by the research subject. Based on the objectives to be achieved in this research, an in-depth study is needed on a data source's natural setting or context. Because what is being studied is the natural background or context of a whole, the research approach that is considered appropriate to be used is a qualitative approach.

\subsection{Data Acquisition Techniques}

Researchers adopted the opinion of Lofland \& Lofland [46], the steps for data collection were carried out through:

a) Primary data is data obtained by researchers directly (from first hand or informants) in the form of information and perceptions and responses related to this research. To obtain primary data, researchers used the following methods:

1. In-depth interview, interviews are a vital data collection tool in qualitative research involving humans as subjects (actors or actors) connected with the reality of symptoms selected or studied.

2. Observation (Observation), observation collects data by direct observation and systematic recording of the object to be studied.

b) Secondary data is data collected from second-hand or other sources that were available before the research was conducted. To obtain secondary data, researchers used the following methods: 
1. Literature study, a literature study is a way to collect data by using and studying existing literature books to look for conceptions and theories closely related to the problem.

2. Documentation, the documents used can be in the form of archived documentation from the website of the Provincial Government of the Special Capital Region of Jakarta and photos related to research. Documentation techniques are carried out to complete data that are not obtained from the interview process to verify the data obtained by researchers.

\subsection{Data Analysis Technique}

In this study, data analysis is very dependent on the type of strategy used; qualitative research generally uses general procedures and specific steps in data analysis. The ideal way is to mix these general procedures with specific steps. The researcher further views qualitative data analysis as a process of applying steps from the specific to the general with different levels of analysis [47; 48; 49]. This approach can be described in more detail in the following analytical steps: The first step is to process and prepare the data for analysis. This step involves transcribing interviews, scanning material, typing field data, or sorting and organizing the data into different types depending on the source of information. The second step, read the accurate data. This step is to build a general sense of the information obtained and reflect on its overall meaning. What are general ideas contained in the participant's words? What is the impression of the depth, credibility, and narrative of the information? At this stage, the researcher sometimes writes special notes or general ideas about the data obtained.

The third step is to analyze in more detail by coding the data. In this third step, the researcher uses data coding, divided into 3 (three) types or types of data analysis processes (coding), namely Open Coding, Axial Coding, and Selective Coding. The fourth step involves using the coding process to describe the settings, people, categories, and themes analyzed. This description involves conveying detailed information about people, locations, or events in a particular setting. Researchers can create codes to describe all this information and then analyze it for a case study project, ethnography, or narrative research. Step 5: Show how these descriptions and themes will be restated in a narrative or qualitative report. The most popular approach is to apply a narrative approach in conveying the results of the analysis. The sixth step, the last step in data analysis, is to interpret or interpret the data. Ask questions like "What lessons can be learned from all this?" will help researchers uncover the essence of an idea [50].

\section{Result and Discussion}

\subsection{DKI Jakarta Information and Documentation Management Official Website}

The Website of the Information Management and Documentation Officer (PPID) of the DKI Jakarta Provincial Government (ppid.jakarta.go.id) is one of the subdomains of the DKI Jakarta Provincial Government's official website. It is namely www.jakarta.go.id, which was built or developed in late 2016 and has been operational since early 2017. The website for the Information Management and Documentation Official (PPID) of the DKI Jakarta Provincial Government was specifically created to implement the Public Information Disclosure Policy by opening access to the public to apply for Public Information online or online. 


\subsection{Implementation of Public Information Disclosure Policy}

In this study, researchers used the theory of policy implementation according to Edwards III there are four indicators in policy implementation, namely:

a) Communication

Communication is one of the crucial factors that determine the successful implementation of a public policy. In communication is divided into two aspects, namely internal and external; following the study results that the communication between the internal parties of the DKI Jakarta PPID went well. In addition, the DKI Jakarta PPID communication with external parties such as with the community is also going well. Suppose there is a lack of completeness of data in submitting a request for information. In that case, the DKI Jakarta PPID website management team will convey information to the applicant to immediately complete the deficiency.

b) Resources

Human resources are one of the variables that affect the success of policy implementation. Based on the research results on the DKI Jakarta PPID website management, the public information service section team has recruited skilled workers as the DKI Jakarta PPID information management team such as programmers, graphic design, and web design, technical support, or IT. The DKI Jakarta PPID information management team consists of about eight people who serve as staff to assist the service process and public information management. With these eight staff, the information management of the DKI Jakarta PPID is considered adequate. It has been running well, as evidenced by the three years that DKI Jakarta has received informative qualifications from the central information commission in the award of public information disclosure.

c) Disposition

One of the factors that influence the effectiveness of policy implementation is the attitude of the implementor. The study results explain that the policies of all leaders in DKI Jakarta are indeed concerned about Public Information Openness. His attitude is very supportive and positive and always provides direction in openness and transparency in public bodies.

d) Bureaucratic Structure

According to Edward III in Widodo (2010:106), this bureaucratic structure includes structure, division of authority, relationships between organizational units. Based on the research, the division of authority and responsibility between sections in the DKI Jakarta PPID follows the Decree of the Governor of the Special Capital Region of Jakarta Number 839 of 2017 concerning Information and Documentation Management Officers.

\subsection{Application of Good Governance Principles}

In this study, the researcher uses the theory of Good Governance principles according to the Good Governance Development Team (BPKP). There are five indicators, namely:

a) Participation

Participation is the principle that everyone has the right to decision-making in every government administration activity. Involvement decision-making can be done directly or indirectly. The results of this study state that the delivery of ideas from website managers is submitted directly to supervision. Then the submission of ideas will be discussed together. If the idea can be applied and is suitable to become a policy at the provincial level, then it can be implemented and implemented. 
b) Transparency

Transparency is the principle of openness that allows the public to know and get the broadest possible access to information. With transparency, it can guarantee access or freedom for everyone to obtain information about government administration, namely information about the policy-making process, its implementation, and the results achieved. In this study, the PPID website of the Provincial Government of DKI Jakarta is not only a regular website. However, it is an information system for the PPID of the Provincial Government of DKI Jakarta. There is a dashboard system as management or managed by regional apparatus, then from the dashboard will publish data that is indeed for the public.

c) Accountability

The accountability aspect allows the public to measure the success or failure of implementing a policy in government administration. In managing the PPID website for DKI Jakarta Province, a Standard Operating Procedure (SOP) has been set to submit public information requests. The information or data requested by the applicant for public information has been confirmed to the relevant work unit for approval so that the information provided to the applicant is valid and can be accounted for.

d) Independence

In carrying out its roles and responsibilities, the government must be free from all forms of possibilities that can cause conflicts of interest. Regarding the aspect of independence, managing the DKI Jakarta Province PPID website is managed by itself with skilled personnel or managers, and there is no third party that manages the DKI Jakarta PPID website.

e) Accountability

Organizations must comply with laws and regulations and carry out their responsibilities to society and the environment so that sustainability can be maintained a business in the long term. Each individual is responsible for all his actions by the assigned tasks. This study states that the implementer's commitment to implementing Public Information Disclosure is very high and transparent. It can even be said that the commitment at PPID DKI Jakarta Province is quite beyond the limits of the Public Information Disclosure required by the Public Information Disclosure Act.

\subsection{Supporting Factors}

\section{a) Budget}

Supporting factors for the Public Information Disclosure Policy in the Implementation of Good Governance Principles from the budget side, namely all sources of funds for website management, come from the DKI Jakarta Provincial Budget. The name of the activity in the APBD is the management and service of Public Information through the DKI Jakarta Provincial PPID. The DKI Jakarta Provincial PPID budget is devoted to service management, payment of human resources outside of ASN/PNS, such as skilled/expert staff, IT, and information service personnel. The DKI Jakarta Provincial PPID budget includes activities such as a technical guidance communication forum that uses expert sources. The PPID budget for DKI Jakarta Province is sufficient to implement website management tasks or public information services. In addition, the budget allocation is also used for supporting facilities and infrastructure. According to the Head of the Public Information Services Section of the Information Management and Documentation Officer (PPID) of the DKI Jakarta Provincial Government, the budget allocated to date is appropriate. It can still be used to implement 
website management tasks or Public Information services through the DKI Jakarta Provincial PPID.

\section{b) Facilities and Infrastructure}

The support of the DKI Jakarta Provincial Government in implementing public information disclosure policies supports the management of the PPID website. It is the existence of positive leadership commitments, support for facilities and infrastructure, budget, human resources, and others. These aspects become essential supports in the management of public information. The devices used by the information service team include computers, faxes, telephones, printers, and others. Meanwhile, the supporting facilities for website management are more device because it talks about information systems technology. However, the primary means of supporting public information services is the server, which stores public information data. The internet network to assist the performance of the DKI Jakarta Provincial PPID website management has also been fulfilled.

\section{c) Human Resources}

Support for human resources provides technical guidance at least once a year to classify Public Information and follow up on incoming public information requests. The obstacles encountered in the implementation of the Public Information Disclosure Policy in the application of the principles of Good Governance include:

1. Developments in the DKI Jakarta Province PPID website are still needed as an effort to provide information following technological developments.

2. When there is a technology update, it must be developed again.

3. Other regional apparatuses in managing public information often have debates regarding information that is private, excluded, or transparent.

4. Barriers to the inner side, namely the existence of a consequence test to determine the information being provided is private or public. A consequence test under the regulations of the information commission is a classification of public information. The PPID of DKI Jakarta Province carries out this consequence test to determine whether the information to be provided to the public is personal data or not. This consequence test is carried out using the matrix method by looking at whether it is personal data or not, and the information that will be provided will have an impact on endangering institutions or the state. If anyone meets these qualifications, then the information will be excluded.

\subsection{Community Assessment}

Based on the results of the first discussion regarding the Implementation of the Public Information Disclosure Policy on the application of the principles of Good Governance on the website management of the Provincial Government of the Special Capital Region of Jakarta, the researchers divided the public's assessment based on four categories in table 2. below this.

Table 2. Community Assessment

\begin{tabular}{ll}
\hline Category & Description \\
\hline & $\begin{array}{l}\text { Disclosure of information is crucial for the community because each } \\
\text { person needs information. } \\
\text { PPID DKI Jakarta Province as a media bridge for }\end{array}$ \\
\hline
\end{tabular}




\begin{tabular}{|c|c|}
\hline Category & Description \\
\hline \multirow{4}{*}{ Public service } & the community to obtain information \\
\hline & $\begin{array}{l}\text { The public can apply for information so that they can quickly get the } \\
\text { data they need }\end{array}$ \\
\hline & $\begin{array}{l}\text { Content available on the website is already quite informative, for PPID } \\
\text { always uploads all the Government of DKI Jakarta activities. }\end{array}$ \\
\hline & $\begin{array}{l}\text { Already quite satisfied with the information provided and the speed } \\
\text { of the DKI Jakarta Provincial PPID website management team. }\end{array}$ \\
\hline \multirow{7}{*}{$\begin{array}{l}\text { Suitability } \\
\text { requirements with the } \\
\text { type of service that } \\
\text { is available }\end{array}$} & $\begin{array}{l}\text { Related complaints, team manager PPID Province of DKI Jakarta } \\
\text { responds with good. If there are problems, then respond quickly. }\end{array}$ \\
\hline & The DKI Jakarta PPID website is already excellent and effective. \\
\hline & $\begin{array}{l}\text { Information about any problems in DKI Jakarta is good enough to fulfill } \\
\text { the required information. }\end{array}$ \\
\hline & The action is by the SOP from PPID DKI Jakarta Province \\
\hline & Data were obtained already valid and can be accounted for \\
\hline & The steps for submitting the information are also accessible. \\
\hline & The principle of transparency that is implemented is also excellent \\
\hline \multirow{2}{*}{$\begin{array}{l}\text { Clarity and certainty } \\
\text { of service time }\end{array}$} & $\begin{array}{l}\text { The website contains information in the form of documentation of DKI } \\
\text { Jakarta government activities }\end{array}$ \\
\hline & Responses were given quite fast, very good, and easy to understand \\
\hline \multirow{3}{*}{$\begin{array}{l}\text { Community } \\
\text { expectations }\end{array}$} & $\begin{array}{l}\text { Estimation process request information } 7-10 \text { days and the data are given } \\
\text { appropriate time and classified detail and can accountable }\end{array}$ \\
\hline & $\begin{array}{l}\text { The website management team can increase interaction and coordination } \\
\text { with the community. It can be through social media because many } \\
\text { people do not know about the DKI Jakarta Provincial PPID website }\end{array}$ \\
\hline & $\begin{array}{l}\text { The team manager of the website can } \\
\text { be more effective for dissemination to the broader community so that the } \\
\text { community can use it. }\end{array}$ \\
\hline
\end{tabular}

Source: Processed by Researchers

\section{Conclusions}

It can be concluded that the Application of Good Governance Principles Management of the Website of the Provincial Government of the Special Capital Region of Jakarta that the content available on the website is quite informative because PPID always uploads all activities of the DKI Jakarta Government. Regarding complaints, in submitting requests for information, the DKI Jakarta Provincial PPID management team responded well. If there were problems, they immediately responded. The public also considered that any problems in DKI Jakarta were good enough to fulfill the required information. For Standard Operating Procedures, the first page directly describes the SOP and directs how to request information. As a whole, the DKI Jakarta PPID website has been running quite well, although there are still shortcomings in providing information or content that is less interesting.

The researchers make the following recommendations 1) The lack of a website management team for the DKI Jakarta Provincial Government Information and Documentation Management Officer, specifically a lack of widespread socialization to reach people who require information from the DKI Jakarta Provincial Government but are unaware of the website. 2) It is necessary to maintain a chat hotline on the DKI Jakarta Provincial Government Information and Documentation Management Officer (PPID) website so that 
people who want to communicate simply can do so.2) It is necessary to maintain a chat hotline on the DKI Jakarta Provincial Government Information and Documentation Management Officer (PPID) website so that people who want to communicate can do so. 3) There must be an integration of social media owned by the Information Management and Documentation Officer (PPID) of the DKI Jakarta Provincial Government with the website because, in this digital era, most people open social media more often than websites. It is because the appearance of social media is generally more straightforward and more attractive.

\section{References}

[1] Vibert, F. (2007). The rise of the unelected: democracy and the new separation of powers. Cambridge University Press.

[2] Beetham, D. (2004). The quality of democracy: Freedom as the foundation. Journal of Democracy, 15(4), 61-75.

[3] Carrera, S., Guild, E., \& Hernanz, N. (2013). The triangular relationship between fundamental rights, democracy and the rule of law in the EU: towards an EU Copenhagen mechanism.

[4] Lee-Geiller, S., \& Lee, T. D. (2019). Using government websites to enhance democratic E-governance: A conceptual model for evaluation. Government Information Quarterly, 36(2), 208-225.

[5] Peled, R., \& Rabin, Y. (2010). The constitutional right to information. Colum. Hum. Rts. L. Rev., 42, 357.

[6] O'Flaherty, M. (2012). Freedom of expression: article 19 of the international covenant on civil and political rights and the human rights committee's general comment no 34. Human Rights Law Review, 12(4), 627-654.

[7] Aldiyarova, A. (2018). The Right of Access to Information Through the Internet: the Comparison of "Hard law" and "Soft law". Malaysian Journal of Social Sciences and Humanities (MJSSH), 3(2), 17-23.

[8] Gupta, J., \& Vegelin, C. (2016). Sustainable development goals and inclusive development. International environmental agreements: Politics, law and economics, 16(3), 433-448.

[9] de Sousa Monteiro, M., Viana, F. L. E., \& de Sousa-Filho, J. M. (2018). Corruption and supply chain management toward the sustainable development goals era. Corporate Governance: The International Journal of Business in Society.

[10] Setyawan, B. (2021). The Existence of Public Information Commission Related to Public Information Disclosure Principles in Improving Public Services by the State. Yuridika, 36(3), 545-558.

[11] Jannah, L. M., Sipahutar, M. Y., \& Hariyati, D. (2020). Public Information Disclosure: Mapping the Understanding of Multiple Actors in Corruption-Prone Indonesian Provinces. Policy \& Governance Review, 4(3), 167-181.

[12] Juiz, C., Guerrero, C., \& Lera, I. (2014). Implementing good governance principles for the public sector in information technology governance frameworks. Open Journal of Accounting, 2014.

[13] Charlick, R. B. (2001). Popular participation and local government reform. Public Administration and Development, 21(2), 149-157.

[14] Charlick, R. B. (2019). Niger: personal rule and survival in the Sahel. Routledge. 
[15] Liu, J., \& Lin, B. (2012). Government auditing and corruption control: Evidence from China's provincial panel data. China Journal of Accounting Research, 5(2), 163-186.

[16] Naidoo, G. (2012). The critical need for ethical leadership to curb corruption and promote good governance in the South African public sector. Journal of Public Administration, 47(3), 656-683.

[17] Warf, B. (2016). Global geographies of corruption. GeoJournal, 81(5), 657-669.

[18] Sumartias, S., \& Amina, N. W. R. (2019). The Challenges of Government Public Relations and Abuse of Power over Indonesia. In ACHITS 2019: Proceedings of the 1st Asian Conference on Humanities, Industry, and Technology for Society, ACHITS 2019, 30-31 July 2019, Surabaya, Indonesia (p. 66). European Alliance for Innovation.

[19] Supranoto, M., \& Novita, D. (2019, October). A Qualitative Meta-analysis on Studies of Local Level Public Services Innovation in Indonesia. In Proceedings International Conference on Innovations in the Social Sciences and Humanities (ISSH). Universitas Jember.

[20] Haskell, J. (2018). Direct democracy or representative government? Dispelling the populist myth. Routledge.

[21] Ahmadi, D., \& Rachmiatie, A. (2019). Public Participation Model for Public Information Disclosure. Jurnal Komunikasi: Malaysian Journal of Communication, 35(4).

[22] Ganie-Rochman, M., \& Achwan, R. (2009). Civic organisations and governance reform in Indonesian cities. Asian Journal of Social Science, 37(5), 799-820.

[23] Peters, B. G., \& Pierre, J. (2006). Governance, government and the state. The state: Theories and issues, 209-222.

[24] Fang, Z. (2002). E-government in digital era: concept, practice, and development. International journal of the Computer, the Internet and management, 10(2), 1-22.

[25] Fiszbein, A., \& Lowden, P. (Eds.). (1999). Working Together for a Change: government, business, and civic partnerships for poverty reduction in Latin America and the Caribbean. World Bank Publications.

[26] Khamis, K. J. (2014). The role of the United Nations development program in promoting good governance: a case study of Zanzibar (Doctoral dissertation, The University of Dodoma).

[27] Shananbli, J. I. H. A. N. (2012). Good governance. AGORA Int'l J. Jurid. Sci., 176.

[28] Charlick, R. B. (2019). Niger: personal rule and survival in the Sahel. Routledge.

[29] Landell-Mills, P., \& Serageldin, I. (1991). Governance and the development process. Finance \& Development, 28(003).

[30] Agere, S. (2000). Promoting good governance: Principles, practices and perspectives (Vol. 11). Commonwealth Secretariat.

[31] Basu, S. (2004). E-government and developing countries: an overview. International Review of Law, Computers \& Technology, 18(1), 109-132.

[32] Chandler, J., \& Kennedy, K. S. (2015). A network approach to capacity building. National Council of Nonprofits, Washington, DC.

[33] Masuku, T. A., Mutangira, J. P., \& Masuku, M. B. (2016). Governance and Accountability of Multi-Purpose Cooperatives in the Shiselweni Region of Swaziland: Implications for Education and Training. Governance, 7(22).

[34] Purnama, S. A., \& Bestari, P. (2020). Implementation of National Medium Term Development Plan (RPJMN) of the Nawacita Program in Improving Good Governance. In Journal of International Conference Proceedings (JICP) (Vol. 3, No. 4, pp. 77-83). 
[35] BPKP, P. P. (2013). Tahun 2014.

[36] Van Meter, D. S., \& Van Horn, C. E. (1975). The policy implementation process: A conceptual framework. Administration \& Society, 6(4), 445-488.

[37] Van Horn, C. E., \& Van Meter, D. S. (1977). The implementation of intergovernmental policy. Policy studies review annual, 1(1), 97-120.

[38] Mazmanian, D. A., \& Sabatier, P. A. (1980). A multivariate model of public policymaking. American journal of political science, 439-468.

[39] Edwards III, G. C. (2008). On deaf ears. Yale University Press.

[40] Russell, M. A., Hill, K. D., Blackberry, I., Day, L. M., \& Dharmage, S. C. (2008). The reliability and predictive accuracy of the falls risk for older people in the community assessment (FROP-Com) tool. Age and ageing, 37(6), 634-639.

[41] Martini, L. K. B., Suardana, I. B. R., \& Astawa, I. N. D. (2018). Dimension Effect of Tangibles, Reliability, Responsiveness, Assurance, Empathy, Leadership towards Employee Satisfaction. International Research Journal of Management, IT and Social Sciences, 5(2), 210-215.

[42] Prakoso, A. F., Nurul, R., Wulandari, A., Trisnawati, N., Fitrayati, D., Rachmawati, L., \& Andriansyah, E. H. (2017). Reliability, Responsiveness, Assurance, Empathy, and Tangible: Still Can Satisfy The Customer. International Journal of Business and Management Invention, 6(3), 68-75.

[43] Yarimoglu, E. K. (2014). A review on dimensions of service quality models. Journal of marketing management, 2(2), 79-93.

[44] Bada, S. O., \& Olusegun, S. (2015). Constructivism learning theory: A paradigm for teaching and learning. Journal of Research \& Method in Education, 5(6), 66-70.

[45] Goddard, W., \& Melville, S. (2004). Research methodology: An introduction. Juta and Company Ltd.

[46] Atkinson, P., Coffey, A., Delamont, S., Lofland, J., \& Lofland, L. (Eds.). (2000). Handbook of ethnography. Sage.

[47] Sgier, L. (2012). Qualitative data analysis. An Initiat. Gebert Ruf Stift, 19, 19-21.

[48] Bazeley, P. (2013). Qualitative data analysis: Practical strategies. sage.

[49] Houghton, C., Murphy, K., Shaw, D., \& Casey, D. (2015). Qualitative case study data analysis: An example from practice. Nurse researcher, 22(5).

[50] Lincoln, Y. S., \& Guba, E. G. (1985). Naturalistic inquiry. sage. 